\title{
Penerapan Desain Pembelajaran Tematik Integratif Alternatif Berbasis Kearifan Lokal untuk Meningkatkan Hasil dan Kebermaknaan Belajar
}

\author{
Ni'matul Khoeriyah' \& Mawardi²
}

'Prodi Pendidikan Profesi Guru, Universitas Kristen Satya Wacana Jl. Diponegoro No. 54-60, Salatiga 50711, Indonesia Email: 952017038@student.uksw.edu

2Pendidikan Guru Sekolah Dasar, Universitas Kristen Satya Wacana Jl. Diponegoro No. 54-60, Salatiga 50711, Indonesia Email: mawardi@staff.uksw.edu

\begin{tabular}{|c|c|}
\hline ABSTRACT & ABSTRAK \\
\hline $\begin{array}{l}\text { This research aims to improve the outcomes and } \\
\text { meaningfulness of learning by applying } \\
\text { alternative integrative thematic design based on } \\
\text { local wisdom. This study is a class action research } \\
\text { on the Stringer model which carried out in two } \\
\text { cycles. Data collection instruments used were } \\
\text { question instruments, observation sheets, } \\
\text { questionnaires, and documentation. Data } \\
\text { analysis was done by a comparative description. } \\
\text { The result of the research showed an increase in } \\
\text { outcomes and the significance of meaningful } \\
\text { learning. It was supported by the thoroughness of } \\
\text { thematic learning outcomes in Indonesian } \\
\text { language, IPS, and PPKn respectively in the } 1 \mathrm{st} \\
\text { cycle } 72,5 \%, 52,5 \% \text {, and } 65 \% \text {. The result of the } 2 \text { nd } \\
\text { cycle was } 90 \%, 75 \% \text {, and } 77,5 \% \text {. Furthermore, the } \\
\text { significant increase of learning meaningfulness in } \\
\text { categories is shown in } 1 \text { st cycle which was } 87.5 \% \\
\text { and increased to } 95 \% \text { in } 2 \text { nd cycle. To conclude, } \\
\text { the outcomes and learning meaningfulness of } \\
4 \text { th grade SDN Gendongan } 02 \text { are improved by } \\
\text { alternative integrative thematic learning based } \\
\text { on local wisdom. }\end{array}$ & $\begin{array}{l}\text { Penelitian ini bertujuan untuk meningkatkan hasil } \\
\text { dan kebermaknaan belajar dengan } \\
\text { menggunakan desain pembelajaran tematik } \\
\text { integratif alternatif berbasis kearifan lokal. } \\
\text { Penelitian ini, penelitian tindakan kelas model } \\
\text { Stringer yang dilaksanakan sebanyak dua siklus. } \\
\text { Instrumen pengumpulan data menggunakan } \\
\text { instrumen soal, lembar observasi, angket, dan } \\
\text { dokumentasi. Analisis data menggunakan } \\
\text { deskripsi komparatif. Hasil penelitian } \\
\text { menunjukkan adanya peningkatan hasil dan } \\
\text { kebermaknaan belajar. Hal ini didukung dengan } \\
\text { data yang menunjukkan ketuntasan hasil belajar } \\
\text { tematik pada muatan Bahasa Indonesia, IPS, } \\
\text { dan PPKn secara berturut-turut pada siklus } \\
72,5 \% \text {, } 52,5 \% \text {, dan } 65 \% \text { Kemudian meningkat } \\
\text { pada siklus II yaitu } 90 \% \text {, } 75 \% \text { dan } 77,5 \% \text {. } \\
\text { Selanjutnya peningkatan kebermaknaan belajar } \\
\text { pada kategori sangat bermakna ditunjukkan } \\
\text { pada siklus I sebesar } 87,5 \% \text { dan meningkat } \\
\text { menjadi 95\% disiklus II. Dengan demikian, } \\
\text { penerapan pembelajaran tematik integratif } \\
\text { alternatif berbasis kearifan lokal dapat } \\
\text { meningkatkan hasil dan kebermaknaan belajar } \\
\text { peserta didik kelas } 4 \text { SDN Gendongan 02. } \\
\text { Kata Kunci: tematik integratif, kearifan lokal, hasil } \\
\text { belajar, kebermaknaan belajar. }\end{array}$ \\
\hline
\end{tabular}

How to Cite: Khoeriyah, N., \& Mawardi, M. (2018). Penerapan Desain Pembelajaran Tematik Integratif Alternatif Berbasis Kearifan Lokal untuk Meningkatkan Hasil dan Kebermaknaan Belajar. Mimbar Sekolah Dasar, 5(2), $63-74$. doi:http://dx.doi.org/10.17509/mimbar-sd.v5i2.11444.

PENDAHULUAN $\quad$ KurikUlum 2013

merupakan kurikulum yang diberlakukan pada pendidikan tingkat dasar dan menengah. Permendikbud No. 24 Tahun
2016 tentang Kompetensi Inti dan Kompetensi Dasar, merumuskan penerapan kurikulum 2013 dalam proses pembelajarannya disajikan dengan 
Ni'matul Khoeriyah \& Mawardi, Penerapan Desain Pembelajaran Tematik Integratif...

menggunakan pendekatan tematik integratif. Mawardi (2014, p. 109) menuliskan pembelajaran tematik integratif merupakan pembelajaran yang menggunakan tema sebagai pemersatu kegiatan pembelajaran yang memadukan beberapa muatan pelajaran dalam satu kali tatap muka. Adapun salah satu faktor pendukung diberlakukannya pembelajaran tematik integratif karena memiliki arti penting sebagai berikut: (1) peserta didik melihat dunia sebagai suatu keutuhan yang terhubung, (2) muatanmuatan pelajaran di SD menghasilkan banyak keluaran yang sama, dan (3) terdapat keterpaduan konten pada berbagai muatan pelajaran yang akan meningkatkan hasil pembelajaran siswa (Kemdikbud, 2014, p. 66; Hanifah, (2014, p. $5)$.

Menurut Astutik (2016, p. 352), dalam pembelajaran tematik peserta didik tidak lagi belajar menggunakan muatan pelajaran seperti IPA, Bahasa Indonesia, Matematika, atau muatan pelajaran lainnya. Peserta didik belajar tema yang di dalamnya sudah mencakup beberapa muatan pelajaran beserta kompetensinya. Selain itu, dalam pembelajaran tema antar muatan pelajaran dilebur menjadi satu sehingga peserta didik tidak merasakan perpindahan antarmuatan pelajaran tersebut. Pembelajaran tematik terpadu ini bertujuan agar peserta didik lebih mudah melakukan observasi, bertanya, bernalar, dan mengomunikasikan apa yang telah diserap selama proses pembelajaran. Hal ini sesuai dengan pendekatan yang ditekankan dalam kurikulum 2013 yaitu pendekatan saintifik.

Kurikulum 2013 menuntut proses pelaksanaan pembelajaran dilakukan secara tematik integratif, maka pembelajarannya harus benar-benar menggunakan tematik integratif secara utuh. Pembelajaran harus sesuai dengan karakteristik pembelajaran tematik integratif, yaitu: (1) berpusat pada peserta didik, (2) memberikan pengalaman langsung (kontekstual), (3) pemisahan muatan pelajaran tidak begitu jelas, (4) menyajikan konsep dari berbagai muatan pelajaran, (5) bersifat luwes (fleksibel), dan (6) hasil pembelajaran dapat berkembang sesuai dengan minat dan kebutuhan siswa (Hernawan, 2009, p. 1).

Pembelajaran tematik integratif melibatkan dalam proses pembelajaran sehingga peserta didik memperoleh pengalaman langsung dan terlatih untuk dapat menemukan sendiri berbagai pengetahuan yang dipelajarinya. Dengan demikian, pembelajaran tematik akan memberikan pengalaman yang bermakna pada peserta didik dalam menyerap pembelajaran. Drake (2012, p. 273) menjelaskan sebagai salah satu strategi pengajaran yang menggunakan tema-tema untuk menciptakan pembelajaran yang aktif, menarik, dan bermakna. Pembelajaran tematik integratif diharapkan dapat menciptakan 
pembelajaran bermakna, yang mendorong peserta didik untuk menemukan pengetahuan dari proses pembelajaran yang dipelajari kemudian dikaitkan dengan pengetahuan yang sudah ada. Hal itu sejalan dengan pandangan Ausubel (Sutisna, Maulana, \& Subarjah, 2016, p. 32) bahwa kegiatan pembelajaran haruslah bermakna yaitu permasalahan yang digunakan dalam pembelajaran relevan dan masih berada dalam jangkauan pengetahuan yang dimiliki peserta didik, Rachmawati (2015, p. 318) menjelaskan pembelajaran menjadi bermakna apabila peserta didik dapat menghubungkan satu konsep dengan konsep lainnya.

Bermakna mempunyai arti peserta didik dapat memahami konsep-konsep yang dipelajari dengan pengalaman langsung dan nyata dalam kehidupan sehari-hari yang menghubungkan antarkonsep dalam intra dan antarmuatan pelajaran. Pembelajaran tematik yang bermakna dapat diwujudkan melalui pembelajaran yang kontekstual yaitu mengaitkan materi pembelajaran dengan dunia nyata di sekitar peserta didik. Salah satu cara yang digunakan untuk menciptakan pembelajaran tematik integratif yaitu melalui penanaman nilai-nilai kearifan lokal dimana peserta didik berada. Hal ini bermanfaat untuk melestarikan dan memertahankan kebudayaan lokal sekaligus membantu peserta didik menghadapi tantangan dunia yang semakin berkembang. Pendidikan diharapkan mampu mewujudkan pembelajaran bermakna dengan berprinsip pada think globally, act locally.

Beberapa penelitian menyatakan bahwa pembelajaran tematik integratif dapat meningkatkan hasil belajar seperti penelitian yang dilakukan oleh Sukerti, Marhaeni, \& Suarni (2015) dan Arifin (2016, p. 19). Di samping itu, penelitian yang dilakukan oleh Dian, Sumarmi, \& Santoso (2016, p. 1) mendeskripsikan bahwa pembelajaran yang kontekstual dapat meningkatkan kebermaknaan belajar.

Kearifan lokal merupakan pandangan hidup dan ilmu pengetahuan serta berbagai strategi kehidupan yang berwujud aktivitas yang dilakukan oleh masyarakat lokal dalam menjawab berbagai masalah dalam pemenuhan kebutuhan mereka (Sumayana, 2017, p. 23). Utari \& Degeng (2016, p. 42) menjelaskan kearifan lokal merupakan kecendikiaan terhadap kekayaan setempat atau suatu daerah berupa pengetahuan, kepercayaan, norma, adat istiadat, kebudayaan, wawasan dan sebagainya yang merupakan warisan dan dipertahankan sebagai sebuah identitas dan pedoman dalam mengajarkan kita untuk bertindak secara tepat dalam kehidupan, sehingga dapat disimpulkan bahwa kearifan lokal merupakan identitas sebuah masyarakat sebagai suatu kekayaan daerah yang berupa pandangan hidup, ilmu pengetahuan, adat istiadat dan kebudayaan. 
Ni'matul Khoeriyah \& Mawardi, Penerapan Desain Pembelajaran Tematik Integratif...

Salah satu lingkup kearifan lokal menurut Wagiran (2013, p. 332) yaitu norma-norma lokal yang mencakup ritual dan tradisi masyarakat seperti, lagu-lagu rakyat, legenda, mitos dan cerita rakyat yang biasanya mengandung pelajaran atau pesan-pesan tertentu yang hanya dikenali oleh komunitas lokal. Oleh karena itu, peneliti menerapkan desain pembelajaran tematik integratif yang dikaitkan dengan kearifan lokal masyarakat Salatiga yakni berupa legenda asal usul terjadinya Salatiga (Bahasa Indonesia), kegiatan ekonomi di Salatiga (IPS) dan karakteristik pekerjaaan di Salatiga (PPKn). Melalui pembelajaran tematik integratif berbasis kearifan lokal dengan tema daerah tempat tinggalku diharapkan akan menambah pengetahuan, meningkatkan hasil belajar dan pengalaman yang bermakna bagi peserta didik

Terkait dengan pelaksanaan kurikulum 2013, SD N Gendongan 02 sudah melaksanakan Kurikulum 2013 dengan menggunakan pendekatan tematik. Sebagai salah satu sekolah inti yang mempunyai visi sekolah berprestasi, bertakwa, terampil yang dijiwai oleh nilainilai budaya karakter bangsa, pelaksanaan kurikulum 2013 sudah diupayakan dengan cara mengirimkan guru untuk melakukan pelatihan kurikulum 2013, workshop, dan kegiatan KKG bersama dengan sekolah-sekolah lainnya. Pelaksanaan pembelajaran tematik integratif di SDN Gendongan 02 juga sudah dilaksanakan berdasakan standar pendidikan kurikulum 2013 dan sudah memenuhi kriteria standar minimal kurikulum yang ditetapkan pemerintah. Akan tetapi, proses implementasi pembelajaran tematik integratif kurikulum 2013 belum optimal karena guru merasa masih kesulitan untuk memadukan muatan pelajaran dalam tema yang sama menjadi sebuah pembelajaran yang benar-benar utuh dan tidak terpisah-pisah. Sehingga pembelajaran tematik yang dilaksanakan belum memberikan makna yang utuh kepada peserta didik seperti tercermin pada berbagai tema yang tersedia.

Penerapan pembelajaran tematik integratif yang bermakna belum sepenuhnya menjadi penekanan. Berdasarkan observasi dan wawancara dengan guru kelas 4 SDN Gendongan 02 pembelajaran kurang bermakna karena kecenderungan pembelajaran yang masih berorientasi pada nilai kognitif. Selain itu, pembelajaran masih terpaku pada buku guru dan buku siswa yang mana dalam buku guru materi terkadang kurang sesuai dengan kondisi lingkungan peserta didik. Hal tersebut berdampak pada perolehan hasil belajar tematik peserta didik.

Data perolehan hasil belajar semester 1 peserta didik kelas 4 pada muatan pelajaran Bahasa Indonesia hanya $41 \%$ (16 peserta didik) dari 39 peserta didik yang mendapat nilai di atas Kriteria Ketuntasan Minimal (KKM) dan 59\% (23 
peserta didik) dari 39 peserta didik mendapat nilai di bawah KKM. Selanjutnya pada muatan pelajaran IPS hanya 44\% (17 peserta didik) yang mendapat nilai di atas KKM dan 56\% (22 peserta didik) mendapat nilai di bawah KKM. Kemudian pada muatan pelajaran PPKn hanya $41 \%$ (16 peserta didik) yang mendapat nilai di atas KKM dan 59\% (23 peserta didik) mendapat nilai di bawah KKM.

Hasil refleksi bersama guru kelas 4 dapat diidentifikasikan beberapa permasalahan sebagai berikut: (1) proses pembelajaran tematik masih terasa terpisah-pisah antarmuatan pembelajaran, (2) bahan ajar terpaku pada buku siswa dan buku guru, (3) pemanfaatan sumber belajar yang ada di lingkungan sekitar peserta didik belum dikaitkan dengan pembelajaran, (4) indikator dan tujuan pembelajaran yang dirumuskan pada rancangan pembelajaran masih berfokus pada ranah pengetahuan.

Menindaklanjuti permasalahan tersebut, peneliti bersama tim kolaborator menyimpulkan permasalahan tersebut termasuk permasalahan yang mendesak dan penting untuk dipecahkan karena apabila tidak segera dipecahkan maka pembelajaran tematik yang seharusnya benar-benar terpadu (integratif) sesuai dengan harapan pemerintah tidak akan terwujud. Peneliti dalam hal ini menggunakan desain pembelajaran tematik integratif alternatif yang dipandang sesuai dengan kearifan lokal di lingkungan sekitar peserta didik.

Peneliti menentukan tindakan inovatif berupa desain pembelajaran tematik integratif berbasis kearifan lokal. Hal ini dikarenakan desain tematik integratif memiliki berbagai manfaat, seperti: (1) fleksibilitas pemanfaatan waktu dan menyesuaikannya dengan kebutuhan peserta didik, (2) menyatukan pembelajaran supaya konvergensi pemahaman yang diperolehnya sambil mencegah terjadinya inkonsistensi antar muatan pelajaran, (3) merefleksikan dunia nyata yang dihadapi peserta didik baik di rumah maupun di lingkungan sekitarnya, serta (4) selaras dengan cara berpikir anak, dimana hasil penelitian otak mendukung teori pedagogik dan psikologi bahwa peserta didik mampu menerima banyak hal dan mengolah serta merangkumnya menjadi satu (Kemdikbud, 2014, p. 67), sedangkan Utari \& Degeng (2014, p. 40) menjelaskan bahwa untuk mengontekstualkan pembelajaran tematik bisa dilakukan melalui penanaman nilainilai kearifan lokal dimana siswa berada.

Dengan demikian, pembelajaran tematik integratif alternatif berbasis kearifan lokal diharapkan dapat membantu siswa memahami pembelajaran secara utuh dan kebermaknaan belajar. Hal ini dikarenakan pembelajaran bersifat kontekstual yang membantu siswa membangun sendiri pengetahuannya berdasarkan pengalaman belajar (MS, Z., 
Ni'matul Khoeriyah \& Mawardi, Penerapan Desain Pembelajaran Tematik Integratif...

2014). Hasil penelitian ini pun diharapkan mampu memberikan manfaat, khususnya pada bidang pendidikan, dengan menjadikan desain pembelajaran tematik integratif alternatif sebagai salah satu cara untuk meningkatkan hasil dan kebermaknaan dalam pembelajaran tematik.

\section{METODE}

Penelitian ini merupakan penelitian tindakan kelas yang menggunakan desain penelitian model Stringer yaitu look, think, dan act (Yaumi \& Damopoli, 2014, p.45). Penelitian dilaksanakan selama 2 siklus. Tahap pertama penelitian ini adalah observasi (look), kemudian peneliti beserta tim kolaborator melakukan refleksi dan memikirkan alternatif pemecahan masalahnya (think), lalu melakukan tindakan (act) berupa pelaksanaan pembelajaran menggunakan model tematik integratif alternatif berbasis kearifan lokal. Penelitian ini dilaksanakan pada semester genap tahun ajaran $2017 / 2018$. Penelitian dilaksanakan di kelas 4 SDN Gendongan 02.

Jenis data yang terdapat pada penelitian tindakan kelas ini adalah data kuantitatif dan kualitatif. Teknik pengumpulan data menggunakan teknik tes dan non tes. Adapun Instrumen penelitian yang digunakan adalah tes, observasi, angket, dan dokumentasi. Untuk memperoleh data hasil belajar menggunakan tes tertulis berbentuk isian singkat, sedangkan untuk memperoleh data kebermaknaan belajar menggunakan instrumen angket. Teknik analisis data dalam penelitian menggunakan deskriptif komparatif yakni dengan membandingkan hasil belajar berdasarkan nilai tes pada setiap siklusnya, sedangkan analisis data kualitatif dilakukan dengan cara analisis deskriptif berdasarkan hasil observasi aktivitas guru dan observasi aktivitas siswa. Penelitian ini dikatakan berhasil apabila ketuntasan hasil belajar peserta didik mencapai $75 \%$ dan skor kebermaknaan belajar masuk dalam kategori bermakna.

\section{HASIL DAN PEMBAHASAN}

Sebelum pelaksanaan siklus, peneliti melaksanakan observasi (look) pada tanggal 19 Maret 2018 terkait dengan pembelajaran tematik yang telah dilaksanakan di kelas 4, kemudian peneliti beserta tim kolaborator melakukan refleksi dan memikirkan alternatif pemecahan masalahnya (think). Pada tahap ini, peneliti menyusun instrumen berupa RPP beserta perangkat pembelajaran lainnya dengan menggunakan desain pembelajaran tematik integratif alternatif berbasis kearifan lokal. Peneliti memilih kearifan lokal sebagai basis dalam pembuatan RPP karena sesuai dengan tema yang sedang berjalan yaitu tema Daerah Tempat Tinggalku. Tema tersebut sangat dekat dengan lingkungan peserta didik sehingga pembelajaran akan lebih bermakna apabila materi yang disajikan dekat dengan pengalaman peserta didik. Hal tersebut sejalan dengan pendapat Mulyasa (2013, p. 103) bahwa dalam 
pembelajaran aktif dan bermakna, setiap materi pelajaran harus dikaitkan dengan pengalaman peserta didik sebelumnya. Oleh karena itu, materi yang disampaikan harus dikaitkan dengan pengalaman yang sudah dimiliki peserta didik dalam kehidupan sehari-hari mereka.

Setelah instrumen disusun dilakukan tindakan (act) berupa pelaksanaan siklus. Siklus I dilaksanakan pada tanggal 22 Maret 2018. Kegiatan pembelajaran terdiri dari tiga muatan pembelajaran yaitu Bahasa Indonesia, IPS, dan PPKn. Pada kegiatan pendahuluan, guru memberikan motivasi dengan melaksanakan tepuk PPK yang sebelumnya belum pernah diperkenalkan kepada peserta didik, sehingga peserta didik terlihat antusias dan semangat. Kemudian guru melakukan apersepsi dengan melakukan tanya jawab terkait dengan lingkungan sekitar tempat tinggalnya. Setelah itu guru menjelaskan tujuan pembelajaran.

Pada kegiatan inti, guru mengaitkan apersepsi yang telah dilakukan pada kegiatan pendahuluan dengan muatan Bahasa Indonesia materi cerita fiksi tentang asal-usul Kota Salatiga, kemudian dikaitkan dengan tokoh cerita fiksi tersebut yang sedang melakukan kegiatan ekonomi pembelajaran IPS terintegrasi di dalamnya. Untuk muatan PPKn juga terintegrasi dengan muatan IPS yakni tentang karakteristik pekerjaan yang dikaitkan dengan kegiatan ekonomi masyarakat lingkungan tempat tinggal peserta didik. Setelah mengetahui perolehan hasil belajar kemudian peneliti bersama kolaborator melakukan refleksi. Berdasarkan perolehan hasil belajar siklus I menunjukkan hasil belajar tematik belum mencapai indikator yang sudah ditentukan yakni ketuntasan belum mencapai 75\%untuk muatan pelajaran IPS dan PPKn. Masih diperlukan upaya perbaikan guna mencapai indikator pada siklus II. Hal ini diduga karena kurang efesiensi waktu dalam pengerjaan lembar kerja peserta didik. Oleh karena itu peneliti dan kolaborator memikirkan langkah perbaikan untuk siklus II (think).

Perbaikan yang dilakukan dengan memperbaiki desain pembelajaran tematik integratif alternatif pada subtema selanjutnya yaitu Bangga Terhadap Daerah Tempat Tinggalku. Pembelajaran pada siklus selanjutnya dengan mengambil daerah yang dibanggakan di lingkungan sekitar Salatiga yaitu Rawa Pening. Kegiatan pembelajaran mencakup tiga muatan seperti pada siklus I yaitu Bahasa Indonesia, IPS, dan PPKn. Muatan Bahasa Indonesia masih terkait dengan tokoh dan penokohan dalam cerita fiksi. Dalam hal ini cerita fiksi yang diambil yaitu cerita fiksi tentang legenda Rawa Pening. Kemudian muatan IPS terintegrasi di dalamnya tentang corak kehidupan masyarakat berdasarkan mata pencaharian di sekitar Rawa Pening. Untuk muatan PPKn tentang manfaat karakteristik individu berdasarkan keanekaragaman mata pencaharian 
Ni'matul Khoeriyah \& Mawardi, Penerapan Desain Pembelajaran Tematik Integratif...

yang terdapat di daerah sekitar Rawa Pening. upaya memperbaiki kekurangan pada siklus I, peneliti merancang kegiatan pembelajaran yang lebih mengefisienkan waktu dalam pengerjaan lembar kerja peserta didik. Setelah rancangan desain pembelajaran tematik terpadu alternatif berbasis kearifan lokal tersusun dengan baik siklus II siap untuk dilaksanakan (act).

Data hasil belajar siklus I diperoleh menggunakan teknik tertulis. Hasil belajar pada siklus I dan siklus || secara rinci disajikan dalam tabel berikut.

Tabel 1. Ketuntasan Hasil Belajar Siklus I dan Siklus II

\begin{tabular}{|c|c|c|c|c|c|c|c|c|c|c|c|c|}
\hline \multirow{3}{*}{ Kategori } & \multicolumn{6}{|c|}{ Siklus I } & \multicolumn{6}{|c|}{ Siklus II } \\
\hline & \multicolumn{2}{|c|}{$\mathrm{BI}$} & \multicolumn{2}{|c|}{ PPKn } & \multicolumn{2}{|c|}{ IPS } & \multicolumn{2}{|c|}{$\mathrm{Bl}$} & \multicolumn{2}{|c|}{ PPKn } & \multicolumn{2}{|c|}{ IPS } \\
\hline & $\mathrm{F}$ & $\%$ & $f$ & $\%$ & $f$ & $\%$ & $f$ & $\%$ & $f$ & $\%$ & $f$ & $\%$ \\
\hline Tuntas & 29 & $72,5 \%$ & 26 & $65 \%$ & 21 & $52,5 \%$ & 36 & $90 \%$ & 31 & $77,5 \%$ & 30 & $75 \%$ \\
\hline Tidak tuntas & 11 & $27,5 \%$ & 14 & $35 \%$ & 19 & $47,5 \%$ & 4 & $10 \%$ & 9 & $22,5 \%$ & 10 & $25 \%$ \\
\hline Total & 40 & $100 \%$ & 40 & $100 \%$ & 40 & $100 \%$ & 40 & $100 \%$ & 40 & $100 \%$ & 40 & $100 \%$ \\
\hline
\end{tabular}

Berdasarkan data pada tabel 1, hasil belajar siklus II lebih besar dibandingkan hasil belajar siklus I. Pada muatan pelajaran Bahasa Indonesia ketuntasan hasil belajar siklus II sebesar $90 \%$ dibandingkan hasil belajar siklus I yaitu 72,5\%. Muatan pelajaran PPKn ketuntasan hasil belajar siklus II sebesar $77,5 \%$ dibandingkan hasil belajar siklus || yaitu 65\%. Sedangkan muatan pelajaran IPS ketuntasan hasil belajar IPS sebesar $75 \%$ dibandingkan hasil belajar siklus I yaitu $52,5 \%$.

Tindakan siklus ॥ dilaksanakan pada 12 April 2018. Pelaksanaan siklus II dilaksanakan sesuai dengan rancangan pelaksanaan pembelajaran. Kegiatan terdiri dari kegiatan awal, inti, dan penutup. Pada kegiatan awal, peserta didik diputarkan sebuah video lagu tentang Kota Salatiga. Setelah itu, peserta didik di eksplorasi pengetahuannya tentang keunikan atau kebanggaan yang dimiliki oleh daerah sekitar Salatiga yaitu salah satunya Rawa Pening. Pada kegiatan inti, peserta didik tampak antusias dalam mengamati tayangan video legenda Rawa Pening. Setelah itu, peserta didik dibentuk kelompok untuk mendiskusikan tokoh utama dan tokoh tembahan yang terdapat pada legenda Rawa Pening. Kemudian dari legenda tersebut dikaitkan dengan corak kehidupan masyarakat di sekitar Rawa Pening dan karakteristik macam-macam pekerjaan yang terdapat di sekitar Rawa Pening. Seluruh lembar kerja peserta didik pada siklus II dikemas dengan diskusi kelompok. Setelah diskusi kelompok selasai, pemaparan hasil diskusi dilakukan secara bergantian dan kelompok lain saling menanggapi pemaparan diskusi tersebut.

Berdasarkan hasil tes formatif pada siklus II, ketuntasan hasil belajar meningkat. Peningkatan ini disebabkan karena 
penerapan desain pembelajaran tematik integratif alternatif berbasis kearifan lokal. Hal tersebut sejalan dengan penelitian yang dilakukan oleh Rozhana (2015) menyatakan penggunaan modul berbasis potensi daerah Malang kelas IV Semester II dengan tema tempat tinggalku menunjukkan ketuntasan yang maksimal dari aktivitas dan hasil belajar siswa. Penelitian lain yang dilakukan oleh Martawijaya (2015, p. 285) menyatakan buku peserta didik berbasis kearifan lokal menempati posisi strategis dalam pembelajaran untuk meningkatkan karakter dan ketuntasan belajar peserta didik.

Selain data hasil belajar pada siklus I dan 2, didapatkan hasil kebermaknaan belajar yang diperoleh dari angket. Pada siklus 1, skor kebermaknaan belajar peserta didik menunjukkan hasil yang baik yaitu dari 40 peserta didik, 35 peserta didik berada pada interval 81-100 (87,5\%) dengan kategori sangat bermakna, dua peserta didik berada pada interval 61-80 (7,5\%) dengan kategori bermakna, satu peserta didik dengan interval 41-60 (5\%) dengan kategori cukup bermakna, dan nol peserta didik dengan interval 21-40 dan 120 (0\%) dengan kategori kurang bermakna dan sangat kurang bermakna. Sedangkan pada siklus II terdapat dari 40 peserta didik, 38 peserta didik dengan interval 81-100 (95\%) dengan kategori sangat bermakna, 2 peserta didik dengan interval 61-80 (5\%) dengan kategori bermakna, dan 0 peserta didik dengan interval 41-60, 21-40, dan 1-20 dengan kategori cukup bermakna, kurang bermakna, dan sangat tidak bermakna. Hasil kebermaknaan belajar secara rinci disajikan dalam tabel 2.

\section{Tabel 2. Pencapaian Kebermaknaan Belajar Siklus I dan Siklus II}

\begin{tabular}{lccccc}
\hline \multirow{2}{*}{ Kategori } & \multirow{2}{*}{ Interval } & \multicolumn{2}{c}{ Siklus I } & \multicolumn{2}{c}{ Siklus II } \\
\cline { 3 - 6 } & & $\mathrm{F}$ & $\%$ & $\mathrm{~F}$ & $\%$ \\
\hline SB & $81-100$ & 35 & $87,5 \%$ & 38 & $95 \%$ \\
B & $61-80$ & 3 & $7,5 \%$ & 2 & $5 \%$ \\
CB & $41-60$ & 2 & $5 \%$ & 0 & $0 \%$ \\
KB & $21-40$ & 0 & $0 \%$ & 0 & $0 \%$ \\
SKB & $1-20$ & 0 & $0 \%$ & 0 & $0 \%$ \\
\hline & Total & 40 & $100 \%$ & 40 & $100 \%$ \\
\hline
\end{tabular}

Peningkatan kebermaknaan belajar dari siklus I dan siklus || merupakan akibat dari penerapan desain pembelajaran tematik terpadu berbasis kearifan lokal. Hal tersebut sejalan dengan penelitian yang dilakukan oleh Amirudin \& Widiati (2017, p. 6) bahwa bahan ajar yang disusun secara kontekstual dapat membantu peserta didik untuk menemukan kebermaknaan belajar. Aisyah, Gipayana \& Djatmika (2017, p. 6) juga menyatakan kebermaknaan belajar dapat diupayakan melalui desain pembelajaran tematik yang terpadu dan holistik dari awal pembelajaran sampai akhir pembelajaran menggunakan model Quantum Teaching. 
Ni'matul Khoeriyah \& Mawardi, Penerapan Desain Pembelajaran Tematik Integratif...

Kompetensi hasil belajar menggunakan Desain Pembelajaran Tematik Integratif Berbasis Pendekatan CTL lebih tinggi daripada Desain Pembelajaran Tematik Integratif yang dijadikan panduan sebelumnya (Saputri \& Mawardi, 2017); Oktavianti \& Wiyanto, 2014).

Selain hasil dan kebermaknaan belajar meningkat, manfaat yang nampak saat pembelajaran salah satunya peserta didik menjadi pembelajar yang aktif. Temuan ini sejalan dengan pernyataan Dewi, Kristianti, \& Negara (2014) yang menyatakan bahwa pembelajaran tematik integratif bernuansa kearifan lokal meningkatkan keaktifan peserta didik dalam bertanya, mencari jawaban, berinteraksi dengan guru dan peserta didik lainnya. Selain itu dengan pembelajaran tematik integratif yang dipadukan dengan kearifan lokal menjadikan peserta didik menghargai nilai-nilai kebudayaan di lingkungan sekitar peserta didik. Hal ini senada dengan pendapat Anwar \& Ruminiati (2017, p. 1010) bahwa langkah awal untuk mencintai NKRI adalah dengan mencintai kearifan lokal daerahnya. Aryawan \& Syahrudin (2013) juga berpendapat bahwa pembelajaran berbasis kearifan lokal mengajak peserta didik untuk selalu dekat dan menjaga keadaan sekitar yang bersifat nilai kekelvargaan dalam bermasyarakat.

Adanya peningkatan hasil dan kebermaknaan belajar peserta didik, tidak lepas dari peran desain pembelajaran tematik integratif berbasis kearifan lokal yang menuntut peserta didik untuk bisa belajar secara aktif dan terlibat secara langsung dalam proses pembelajaran, sehingga siswa memperoleh pengalaman dan pengetahuan yang dipelajarinya. Dengan demikian, secara logis dapat diterima bahwa penerapan desain pembelajaran tematik integratif alternatif berbasis kearifan lokal dapat meningkatkan hasil dan kebermaknaan belajar peserta didik kelas 4 SDN Gendongan 02.

\section{SIMPULAN}

Peningkatan hasil dan kebermaknaan belajar ditunjukkan oleh besarnya persentase hasil belajar yang mencakup tiga muatan pembelajaran yakni Bahasa Indonesia, PPKn, dan IPS. Muatan pelajaran Bahasa Indonesia mencapai ketuntasan sebesar $72,5 \%$ (29 peserta didik), PPkn sebesar 65\% (26 peserta didik), dan IPS sebesar 52,5\% (21 peserta didik). Sedangkan pada siklus II perolehan hasil belajar pada muatan pelajaran Bahasa Indonesia mencapai ketuntasan sebesar 90\% (36 peserta didik), PPKn sebesar 77,5\% (31 peserta didik), dan IPS sebesar 75\% (30 peserta didik). Peningkatan kebermaknaan belajar pada kategori sangat bermakna ditunjukkan pada persentase pada siklus I sebesar 87,5\%, meningkat menjadi $95 \%$ di siklus II. 


\section{REFERENSI}

Aisyah, D. W., Gipayana, M., \& Djatmika, E. T. (2017, June). Mengembangkan Kebermaknaan Belajar dengan Rancangan Pembelajaran Tematik Bercirikan Quantum Teching. In Prosiding Seminar Nasional Mahasiswa Kerjasama Direktorat Jenderal Guru dan Tenaga Kependidikan Kemendikbud 2016.

Amirudin, A., \& Widiati, U. (2017, June). Pentingnya Pengembangan Bahan Ajar Tematik untuk Mencapai Pembelajaran Bermakna bagi Siswa Sekolah Dasar. In Prosiding Seminar Nasional Mahasiswa Kerjasama Direktorat Jenderal Guru dan Tenaga Kependidikan Kemendikbud 2016.

Anwar, M. F. N., \& Ruminiati, S. (2017). Pembelajaran Tematik Terpadu Berbasis Kearifan Lokal Dalam Membentuk Karakter Siswa.

Arifin, S. (2016). Pengaruh Pembelajaran Tematik-Integratif Berbasis Sosiokultural Terhadap Hasil Belajar Peserta Didik Kelas III Di Sekolah Dasar. Profesi Pendidikan Dasar, 3(1), 16-25.

Aryawan, I. P. E., \& Syahruddin, I. G. (2013). Pengaruh Model Pembelajaran TPS Berbasis Kearifan Lokal Terhadap Hasil Belajar IPS Siswa SD. MIMBAR PGSD Undiksha, 1 (1).

Astutik, P. P. (2016). Integrasi Penguatan Pendidikan Karakter (PPK) Dan Higer Order Thinking Skills (HOTS) dalam Pembelajaran Tematik SD.

Dewi, N. W. B. S., Kristiantari, M. R., Negara, I. G. A. O., \& Ke, S. P. M. (2014). Model Tematik Bernuansa Kearifan Lokal Berbantuan Media Animasi Berpengaruh terhadap Hasil Belajar IPA Siswa Kelas III SD Negeri Gugus Kapten Japa. MIMBAR PGSD Undiksha, 2(1).

Dian, I. M., Sumarmi, S., \& Santos, A. (2017, June). Pembelajaran Kontektual untuk Meningkatkan Kebermaknaan Belajar Siswa Sekolah Dasar. In Prosiding Seminar Nasional Mahasiswa Kerjasama Direktorat Jenderal Guru dan Tenaga Kependidikan Kemendikbud 2016.

Drake, S. M. (2012). Creating standards based integrated curriculum: the commom core state standards edition. California: Corwin Press A sage Publication.
Hanifah, N. (2014). RESENSI BUKU: MEMBUKA PIKIRAN MENUJU KETERPADUAN. Mimbar Sekolah Dasar, 1 (1), 108-112. doi:http://dx.doi.org/10.17509/mimbarsd.v1i1.871

Hernawan, A. H. (2009). Pengembangan Model Pembelajaran Tematik Di Kelas Awal Sekolah Dasar.

Indonesia, M. P. (2016). Peraturan Menteri Pendidikan dan Kebudayaan Republik Indonesia Nomor 24 Tahun 2016 tentang Kompetensi Inti dan Kompetensi Dasar Pelajaran pada Kurikulum 2013 pada Pendidikan Dasar dan Menengah. Jakarta: Menteri Pendidikan Dan Kebudayaan Republik Indonesia.

Kemendikbud. 2014. Implementasi Kurikulum 2013. Jakarta: Kemendikbud.

Martawijaya, M. A. (2015). Buku Fisika Peserta Didik Berbasis Kearifan Lokal Untuk Meningkatkan Karakter Dan Ketuntasan Belajar. Jurnal Sains dan Pendidikan Fisika, 10(3).

Mawardi, M. (2014). Pemberlakuan Kurikulum SD/MI Tahun 2013 dan Implikasinya Terhadap Upaya Memperbaiki Proses Pembelajaran Melalui PTK. Scholaria: Jurnal Pendidikan dan Kebudayaan, 4(3), 107121.

MS, Z. (2014). PENDEKATAN KONTEKSTUAL DALAM PEMBELAJARAN MENULIS DI SEKOLAH DASAR (ACTION RESEARCH DI KELAS TINGGI SEKOLAH DASAR). Mimbar Sekolah Dasar, 1(1), 83-91. doi:http://dx.doi.org/10.17509/mimbarsd.v1i1.1363

Mulyasa. (2013). Pengembangan dan Implementasi Kurikulum 2013. Bandung: Remaja Rosdakarya.

Oktavianti, R., \& Wiyanto, A. (2014). PENGEMBANGAN MEDIA GAYANGHETUM (GAMBAR WAYANG HEWAN DAN TUMBUHAN) DALAM PEMBELAJARAN TEMATIK TERINTEGRASI KELAS IV SD. Mimbar Sekolah Dasar, 1(1), 65-70. doi:http://dx.doi.org/10.17509/mimbarsd.v1i1.865

Rachmawati, T., \& Daryanto. (2015). Teori Belajar dan Proses Pembelajaran yang Mendidik. Yogyakarta: Gava Media.

Rozhana, K. M. (2015). Pengembangan Modul Berbasis Potensi Daerah Malang Kelas IV Semester II Dengan Tema 
Ni'matul Khoeriyah \& Mawardi, Penerapan Desain Pembelajaran Tematik Integratif...

$\begin{array}{lll}\text { Tempat } & \text { Tinggalku. } & \text { Malang: } \\ \text { Pascasarjana } & \text { Universitas } & \text { Negeri } \\ \text { Malang. } & & \end{array}$

Saputri, A. T. W., \& Mawardi, M. (2017). Pengembangan Desain Pembelajaran Tematik Integratif Berbasis Pendekatan Contextual Teaching And Learning (CTL) Kelas 4 Sekolah Dasar. Jurnal Pendas, 4(2), 104-114.

Sukerti, N. N., Marhaeni, A. N., \& Suarni, N. K. (2015). Pengaruh Pembelajaran Tematik Terpadu melalui Pendekatan Saintifik terhadap Minat Belajar dan Hasil Belajar Siswa Kelas IV SD Negeri 2 Tibubeneng Kuta Utara. PENDASI: Jurnal Pendidikan Dasar Indonesia, 4 (1).

Sumayana, Y. (2017). Pembelajaran Sastra di Sekolah Dasar Berbasis Kearifan Lokal (Cerita Rakyat). Mimbar Sekolah Dasar, $4(1), 21-28$.
Sutisna, A. P., Maulana, M., \& Subarjah, H. (2016). Meningkatkan Pemahaman Matematis Melalui Pendekatan Tematik dengan RME. Jurnal Pena IImiah, 1(1), $31-40$

Utari, U., \& Degeng, I. N. S. (2016). Pembelajaran tematik berbasis kearifan lokal di sekolah dasar dalam menghadapi Masyarakat Ekonomi Asean (MEA). Jurnal Teori dan Praksis Pembelajaran IPS, 1 (1), 39-44.

Wagiran, W. (2013). Pengembangan Karakter Berbasis Kearifan Lokal Hamemayu Hayuning Bawana (Identifikasi Nilai-Nilai Karakter Berbasis Budaya). Jurnal Pendidikan Karakter, (3).

Yaumi, M., \& Damopoli, M. (2014). Action Research Teori, Model, dan Aplikasi. Jakarta: Prenadamedia Group. 